\title{
Vild geologi - og dramatiske teorier
}

\section{Af geolog Ulla V. Hjuler, GeologiskNyt}

Joseph Kirschvink, professor i geobiologi ved Caltech (California Institute of Technology), kan ikke betegnes som en småkedelig forsker, der med sin forskning luller folk i søvn. Blandt hans teorier finder vi bidrag til for eksempel "Snowball Earth" - teorien om, at hele Jorden frøs til is i prækambrisk tid. I en artikel fra 2000 beskriver han jordskælvsforudsigelse ved hjælp af dyr. Også polvandring har han været rundt om.

En af Dr. Joseph L. Kirschvinks "dramatiske teorier" drejer sig om polvandring - at han og hans gruppe måske har løst dele af mysteriet om "det evolutionære big bang” for ca. 530 mio. år siden, hvor livet på Jorden pludselig blev meget varieret. I Science d. 25. juli 1997 beretter gruppen fra Caltec således, at denne evolutionære eksplosion falder sammen med en anden tilsyneladende unik begivenhed i Jordens historie, nemlig et 90 graders skift i retningen af Jordens spin-akse relativt til kontinenterne.

Kirschvink foreslår, at en stor reorganisering af de tektoniske plader gennem sen Prækambrium ændrede massebalancen inde i Jorden og således udløste den nye orientering. På den måde skulle de områder, der tidligere lå ved nord- og sydpolerne, være flyttet til ækvator, og to punkter beliggende diametralt modsat, der lå nær ækvator, skulle således være blevet de nye poler!

\section{Ubalance i massefordelingen}

Faktisk har geofysikere i mere end et halvt århundrede vist, at den faste del af en planet kan bevæge sig hurtigt i forhold til dens rotationsakse vha. en proces kaldet "true polar wander" (noget i retning af "sand polvandring”). Kirschvink forklarer, at det ikke er det samme som den velkendte pladebevægelse, som er ansvarlig for jordskælv og vulkanisme. Disse processer er styret af varmekonvektion i Jordens kappe, mens "sand polvandring” er forårsaget af en ubalance i massefordelingen af planeten selv, hvilket de fysiske love udjævner i løbet af forholdsvis kort tid. Under denne omfordeling bevæger hele den faste del af planeten sig samlet og undgår derved de indre for-

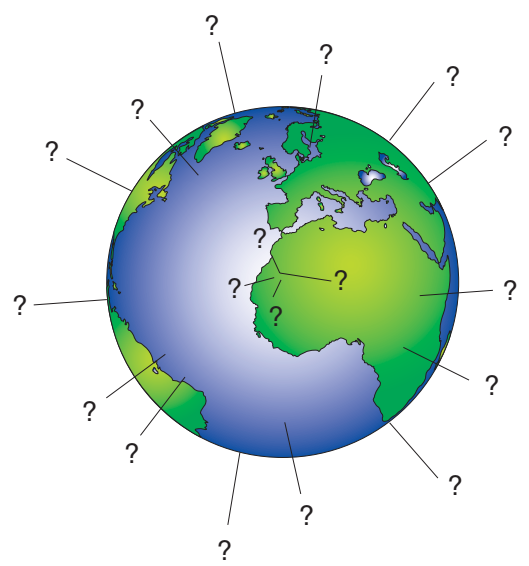

skydningseffekter (shear), som pålægger hastighedsbegrænsningen på traditionelle pladebevægelser. (Mens dette står på, bevarer Jorden naturligvis sin originale spin-akse i forhold til solsystemets plan). Således kan den "sande polvandring" resulterer i, at landmasser bevæger sig hundreder af gange hurtigere end tektonisk bevægelse forårsaget af konvektion.

\section{Andre dramatiske teorier}

Kirschvink har dog nogle hårde konkurrenter, der er svære at overse, når det gælder “dramatiske teorier”!

Charles Hutchins Hapgood var en af forkæmperne for "polskifte-hypotesen". Denne hypotese siger, at rotationsaksen for en planet ikke altid har været, hvor den er nu - eller at aksen ikke vil forblive der. Med andre ord at dens fysiske poler er blevet eller vil blive skiftet. ("Polskifte-hypotesen” skal ikke forveksles med en "magnetisk polvending”, dvs. hvor den magnetiske nord- og sydpol bytter plads).

Samuel Warren Carrey, der i 1946 blev professor på University of Tasmania, forskede på egen hånd i kontinentaldrift. Han konstruerede en stor klode, hvor han "manipulerede rundt” med detaljerede modeller af kontinenterne. Utilfreds med sit resultat konkluderede han til sidst, at kontinenterne kun passede sammen på en klode, der engang havde været mindre! Med denne idé synes mange andre detaljer at falde på plads - teorien blev kaldt for "expanding Earth" - altså teorien, om at Jorden udvider sig, og at kontinenterne bevæger sig væk fra hinanden pga. yderligere udvidelse ved riftzoner, hvor oceanerne oprindeligt lå!

Reference:

Andrew Alden, http://geology.about.com 